2016-03-14

\title{
Union learning representatives in the UK: activity, impact and organization
}

\author{
Saundry, R
}

http://hdl.handle.net/10026.1/4619

10.1177/0950017016630247

Work, Employment \& Society

All content in PEARL is protected by copyright law. Author manuscripts are made available in accordance with publisher policies. Please cite only the published version using the details provided on the item record or document. In the absence of an open licence (e.g. Creative Commons), permissions for further reuse of content should be sought from the publisher or author. 


\section{Union Learning Representatives in the United Kingdom - Activity,}

\section{Impact and Organisation}

Richard Saundry, Plymouth Graduate School of Management, Plymouth University

Valerie Antcliff, Centre for Enterprise, Manchester Metropolitan University

Alison Hollinrake, Institute for Research into Organisations, Work and Employment, University of Central Lancashire

Work, employment and society 1-19, (C) The Author(s) 2016

Reprints and permissions: sagepub.co.uk/journalsPermissions.nav

DOI: $10.1177 / 0950017016630247$ 


\begin{abstract}
The debate over the significance of Union Learning Representatives (ULRs) in the United Kingdom (UK) has become increasingly polarised. Some commentators see little prospect of ULRs contributing to advancing either workplace learning or union organisation due to the constraints of neo-liberal state policy. An opposing view emphasises union agency in developing a collective approach to learning and extended joint regulation through a process of critical engagement. This article presents analysis of data from the 2009 National Survey of ULRs, which finds a positive relationship between ULR activity and its impact in enhancing training outcomes, increasing union membership and the joint regulation of workplace learning. This supports arguments that agency of ULRs is not inevitably suppressed by the structural limitations of union learning.
\end{abstract}

Keywords: Union learning representatives, training, negotiation, renewal, trade unions

Corresponding Author: Richard Saundry, Professor of HRM and Employment Relations, Plymouth Graduate Management School, Mast House, Plymouth University, Drake Circus, Plymouth, PL4 8AA - Email: Richard.Saundry@plymouth.ac.uk 


\section{Introduction}

The Union Learning Representative (ULR) role in the UK has its origins in the establishment of the Union Learning Fund (ULF) in 1998. ULRs are workplace representatives whose primary role is to assist union members in accessing learning, and, in some cases, to consult and negotiate with the employer over these issues. By $2010 / 11$, more than 26,000 had been trained (Unionlearn, 2011). While not all took up the role, of those that did, a significant proportion had not previously held any union position, triggering an injection of new activists into union branches (Saundry et al., 2010; Bacon and Hoque, 2008).

Given the challenges faced by UK trade unions in retaining members and influence, the emergence and development of the ULR role has been seen as making a vital contribution to the revitalisation of union organisation (Lee and Cassell, 2009; Findlay and Warhurst, 2011; Moore, 2011). However, critics argue that the potential of ULR activity is fundamentally restricted by the incorporation of union learning within the UK's neo-liberal approach to vocational education and training (Mcllroy and Croucher, 2009). From this perspective, union learning is reliant on cooperation with the state, which controls access to funding and shapes priorities (Mustchin, 2012), and on the goodwill of employers. Consequently, ULRs are unlikely to have any meaningful impact beyond large workplaces, where trade unions are already strong (Lloyd and Payne, 2006; Mcllroy, 2008).

To examine this debate, Rainbird and Stuart (2011) have set out a conceptual framework based on two competing perspectives. The 'incorporation thesis' emphasises the structural 
inadequacies of union learning. Here, the role of the ULR is restricted to facilitating learning that serves state and employer interests. ULR activity represents a shift away from the traditional bargaining role of the shop steward and crowds out 'grass-roots organising'. In contrast, the 'critical engagement' thesis stresses the influence of union agency. While this perspective recognises the constraints of operating within a voluntarist and neo-liberal training regime, it argues that ULRs can exploit the 'opportunity structure' opened by union learning to shape the collective character of skills development (Cassell and Lee, 2009), increase union organisational capacity and extend joint regulation (Heyes and Rainbird, 2011; Wallis et al., 2005).

This article examines this debate, and explores the tensions between structure and agency that underpin it, using data from the 2009 National ULR Survey, conducted by Unionlearn and designed by the authors. A series of propositions are developed concerning the extent to which the activities of ULRs, and their impact on training and learning, member recruitment and interest in union membership, are related to: workplace characteristics associated with high levels of organisation; managerial support; collective learning institutions; and the conduct of negotiation over learning.

The article argues that there is clear evidence of a positive relationship between ULR activity and its impact, and the joint regulation of workplace learning. This suggests that agency of ULRs is not inevitably suppressed by the structural limitations of union learning. Moreover, extant critiques of the potential role played by union learning representatives in 
strengthening workplace organisation reflect a duality between organising and servicing and organising and partnership that, as Simms and Holgate (2010) have argued in respect of union organising in general, obscures the objectives of union learning, and prevents a clear analysis of the nuanced ways in which ULRs can contribute to union renewal.

The article proceeds as follows: first, research evidence regarding the role played by ULRs is discussed; the methods are then described and the dependent and explanatory variables are specified; results are presented in the form of four regression models that explore measures of ULR activity and impact; finally results are discussed and conclusions are drawn.

\section{Union Learning Representatives - agents of the state?}

The role of ULRs is central to debates over the efficacy of union learning. For critics, the evolution of the ULR function, within the wider structure of union learning, fundamentally constrains its contribution to strengthening union organisation. While a statutory right for (reasonable) paid time off for ULRs was introduced under the Employment Relations Act 2002, ULRs operate within a voluntaristic and neo-liberal training regime (Clough, 2010). For Mcllroy and Croucher (2013:286), this consigns ULRs to the role of 'foot soldiers in the perennial but recharged project of creating a high-skill, flexible, competitive labour market'. 
Consequently, it is argued that ULR activity is subject to managerial discretion and merely acts a 'lubricant' in maximising productivity, with employer support contingent on skills development meeting productive requirements (Mcllroy, 2008:286). Furthermore, scarce union resources are diverted from workplace organising to employer-focussed learning activities. In this context, trade unions are seen as 'state agents' (Ewing, 2005) who attenuate the failure of a market-driven system of skills and training. Therefore, union-led workplace learning is 'implausible' as an engine of revitalisation (Mcllroy, 2008) and is likely to be confined to workplaces where unions are already strong (Lloyd and Payne, 2006).

This critique reflects a fundamental rejection of the emphasis placed by some unions on partnership working and the provision of individual services to members. Rather than independent activists concerned primarily with collective bargaining, ULRs are integrated into 'management goals' (Mcllroy and Croucher, 2009:294) and limited to providing learning advice and courses for members. Therefore, they are incapable of contributing to 'adversarial grass-roots organising' and consequently to union renewal (Mcllroy and Croucher, 2009:263).

While the 'critical engagement thesis' acknowledges the structural limitations of union learning, it stresses the potential of union agency; the ability of ULRs to 'critically engage' with the environment in which they find themselves and to create new channels of voice where conventional collective influence is currently stifled (Moore, 2011; Rainbird and Stuart, 2011). Thus, ULRs can develop an agenda independent of employers' interests (Wallis et al., 2005) and recast learning as a collective issue (Cassell and Lee, 2009). 
The critical engagement thesis rejects the separation between the bargaining role of the shop steward and the advisory orientation of the ULR. Instead, it suggests that they are critically intertwined in three respects. First, ULR activity stimulates recruitment of new members by demonstrating the relevance of union membership to workers' personal and professional lives (Thompson et al., 2007; Moore and Wood, 2007). Second, the ULR role attracts new activists, who are more likely to come from groups under-represented within trade unions, extending union reach to less organised areas of the workforce (Wallis et al., 2005). Third, it is argued, that the ULR role offers 'an escalator to wider union activity' (Moore, 2011:77).

\section{Assessing the evidence}

Evidence from a series of national surveys suggest that ULRs have increased awareness of learning opportunities and extended the provision of training (Hoque and Bacon, 2011; Wood and Moore, 2004). Moreover, an evaluation of the Union Learning Fund (Stuart et al., 2013) found that it had expanded access to learning and closed skills gaps. Importantly, it would seem that the impact of union learning reaches beyond employers' interests, extending basic and transferable skills and enhancing employability (Rainbird, 2005; Thompson et al., 2007).

There is also evidence that ULR activity is not confined to the provision of learning 'services'. The 2009 ULR survey found that almost three-quarters of ULRs had recruited, or helped to 
recruit, new members in the previous 12 months (Saundry et al., 2010). While recruitment is not necessarily concomitant with developing organisational capacity, Findlay and Warhurst (2011) found that union learning had a positive impact on union activism. Furthermore, the ULR initiative has drawn a significant number of new activists into trade unions. While nine percent of ULRs in 2000 had no previous union role, this had increased to 37 percent by 2009. The same data found greater ethnic and gender diversity among the ULR community compared to other groups of union activists (Saundry et al., 2010). Nonetheless, there has been concern that 'new activists' are motivated by a narrow interest in learning rather than wider collective concerns (Findlay and Warhust, 2011). Also, early evidence suggested that they may not be integrated into local union structures (Wallis et al., 2005; Rainbird, 2005). However, more recent studies point to a growing acceptance of the ULR role by union branches and ULRs developing wider interests in union issues (Moore, 2011; Stuart et al., 2013).

Critics question this evidence, arguing that it relies on small-scale qualitative studies in highly unionised settings or 'unrepresentative' self-report surveys (Mcllroy and Croucher, 2013:6). They place particular emphasis on Hoque and Bacon's (2008) analysis of the WERS2004, which discovered little positive association between ULR presence and training activity. However, scrutiny of the same survey by Stuart and Robinson (2007) found that ULR presence made it more likely that workers in unionised workplaces would receive training. 
The most recent WERS data provide comfort for both sides of the debate. In 2011, almost one-third of employees had access to a ULR, and the proportion of workplaces with on-site union representation, which had ULRs, increased to 16 percent, from 10 percent in 2004 . There was also a slight increase in the percentage of workplaces where training was negotiated, from 11 to 13 percent. However, ULRs remained concentrated in large, unionised workplaces. There was also a clear divide between the public and private sectors, with public sector workplaces more likely to be 'high trainers' and to negotiate over training (van Wanrooy et al., 2013).

\section{Defining the issues}

While writers associated with the 'incorporation thesis' reject claims of structural determinism (Mcllroy and Croucher, 2013), the two schools of thought are underpinned by different views as to the potential power of union agency in the context of learning. Although Mcllroy and Croucher (2009:297) argue that their rejection of ULRs as 'compelling agents for change' is based on a lack of evidence, their dismissal of the ULR contribution to renewal as implausible reflects a particular conceptualisation of the ULR role, which implies a fundamental dichotomy between unions acting as an 'agent' serving the interests of employers by supplying scarce skills and 'bargaining with management to regulate training and enforce union standards'. This has implications for broader debates over union renewal, juxtaposing as it does adversarial grass-roots organising against partnership and servicing approaches. 
This leads to two very different predictions regarding the potential implications of the ULR initiative. The 'critical engagement thesis' suggests that ULR activity and impact in relation to training and extending union organisation will be associated with the development of collective institutions and the joint regulation of training. In contrast, the 'incorporation thesis' predicts that ULR activity and impact will be more likely in workplaces where trade unions are already well organised and, ultimately, will depend on managerial support. Moreover, it implies a clear disjuncture between the ULR role and collective bargaining.

These two perspectives are reflected in three sets of propositions:

\section{Proposition 1: Levels of ULR Activity in Relation to Training and Learning}

Incorporation thesis:

Proposition 1a - Levels of ULR activity in relation to training and learning will be positively associated with workplace size, union density and sector.

Proposition $1 \mathrm{~b}$ - Levels of ULR activity in relation to training and learning will be higher in workplaces with greater managerial support for learning

\section{Critical engagement thesis:}

Proposition 1c - Levels of ULR activity in relation to training and learning will be greater in workplaces with collective workplace learning institutions. 
Proposition $1 \mathrm{~d}$ - Levels of ULR activity in relation to training and learning will be greater in workplaces where there is negotiation over training and learning.

\section{Proposition 2 - Impact of ULR Activities on Workplace Training}

Incorporation thesis:

Proposition 2a - impact of ULR activities on training and learning will be positively associated with workplace size, union density and being in the public sector.

Proposition $2 \mathrm{~b}$ - impact of ULR activities on training and learning will be greater in workplaces where there is managerial support for learning.

\section{Critical engagement thesis:}

Proposition $2 \mathrm{c}$ - impact of ULR activities on training and learning will be greater in organisations with collective workplace institutions.

Proposition $2 \mathrm{~d}$ - impact of ULR activities on training and learning will be greater in organisations where there is negotiation over training and learning.

\section{Proposition 3 - Impact of ULR Activities on Recruitment and Interest in Union Membership}

Incorporation thesis:

Proposition 3a - recruiting new members and perceived interest in union membership will be positively associated with workplace size, union density and being in the public sector. 
Proposition 3b - recruiting new members and perceived interest in union membership will be greater in workplaces where there is managerial support for learning.

\section{Critical engagement thesis}

Proposition 3c - recruiting new members and perceived levels of interest in union membership will be greater in organisations with collective workplace institutions.

Proposition 3d - recruiting new members and perceived levels of interest in union membership will be greater in workplaces where there is negotiation over training and learning.

\section{Methods}

\section{Sample}

This article analyses data from Unionlearn's 2009 survey of ULRs. Previous surveys were conducted in 2000, 2003, 2005 and 2007. The 2009 survey was the most comprehensive in scope. It was innovative in two key respects; first, whereas previous studies relied on excluding inactive ULRs at the analysis stage, the 2009 survey comprised of separate questionnaires for active and inactive ULRs; second, it introduced questions related to ULR activity in recruiting new members and their impact on interest in union membership. 
The sampling frame was Unionlearn's database of 10,713 individuals who had undergone ULR training. Questionnaires were distributed by post and email to each individual. An initial filter question guided 'inactive' respondents to a separate, shorter, questionnaire that sought to determine reasons for their inactivity. In total, 1,292 ULRs responded to the survey. Of these, 968 responses were received from active ULRs and 324 from inactive ULRs, an overall response rate of 12.1 percent. Only data from active ULRs were used, in order to explore factors that influence current levels of activity and impact. The response rate, while low, is comparable to the 14 percent achieved in the previous survey of ULRs on which subsequent authoritative analyses were based (Bacon and Hoque, 2010; Hoque and Bacon, 2011).

As with all survey data, there was potential for non-response bias. Because only the contact details of non-respondents were available, it was not possible to test whether the demographics of our sample differed significantly from non-respondents. To minimize nonresponse, reminders were issued and an option to complete the questionnaire online was offered. Nonetheless, it is possible that respondents may have particularly strong positive or negative feelings about their role as a ULR. Questions can also arise over the reliability and validity of recall data, especially when the recall period is long and events or outcomes are not memorable (Dex and McCulloch, 1998). As with much previous research (see Mcllroy and Croucher, 2013), the data is based on the perceptions of ULRs, who may be prone to overestimate their own activity and impact. By limiting the recall period to 12 months and asking respondents about events and outcomes that would be noteworthy in their capacity as a ULR, the reliability and validity of the data was maximised. 


\section{Data Analysis}

\section{Dependent variables}

Four dependent variables were used to measure levels of ULR activity and impact. The 2009 survey introduced broader measures of workplace training and learning than previous surveys (see Bacon and Hoque, 2010). Consequently, an index was developed, which measured ULR activity across diverse aspects of the role. A second index was developed to capture ULRs' perceptions of their impact on different types of workplace training and learning. To assess the potential impact of ULRs to contribute to union renewal, two dependent variables were used - having recruited at least one new member in the previous 12 months and perceived interest in union membership.

\section{Level of ULR Activity in Relation to Training and Learning (Activity Index)}

Our index of ULR activity drew on the work of Bacon and Hoque (2009). Using data from the 2007 Survey of ULRs, they suggested that the range of tasks relating to the provision of training performed by a ULR is associated with positive impacts on training. Therefore, three variables were included to capture a range of tasks related to the provision of training information, advice and guidance, whether the respondent had: 'provided information and advice to colleagues on training and learning'; 'helped a colleague to get funding for learning'; 'arranged or helped to arrange courses for colleagues'. However, ULR activity is not concerned solely with providing practical guidance. As argued above, ULRs operate within a voluntaristic and neo-liberal training regime, a consequence of which is that much activity is reliant on managerial support. Providing themselves with information and data to lobby employers can be an important aspect of ULR activity. Following the work of Cassell and Lee 
(2007) and Hoque and Bacon (2011), whether a ULR had 'conducted a learning needs assessment', was included to capture this dimension of activity. A final measure, 'meeting and networking with other ULRs', was designed to reflect the degree of integration in broader union networks, which offer the potential to exercise influence and hence have a positive impact on training and learning (Bacon and Hoque, 2009).

Initially 'recruiting a new member to the union' was included. The six dichotomous responses were used to form a summative scale measuring overall activity. However, an inspection of inter-item and item-total correlations suggested that 'recruiting a new member' was relatively weakly correlated with the scale (Spearman's Rho .193). Removing the item resulted in a small increase in Cronbach's $\alpha$ (from .62 to .64), therefore it was decided not to retain the item in the activity scale, but to include it as a dependent variable, as it appeared to be capturing a separate dimension of union activity. Descriptive statistics for the five- item 'activity' scale are presented in Appendix A.

\section{Impact on Participation in Workplace Training (Training Index)}

Following Bacon and Hoque (2009), our index was designed to capture the breadth of ULRs' perceived impact on training, from basic numeracy and literacy for the most disadvantaged workers, to Continuing Professional Development (CPD) courses, frequently undertaken by graduates and professionals (Unionlearn, 2015). By including variables to measure impact on both recognised vocational, academic and job-related training, participation and perceived impact across a range of transferable and non-transferable skills were captured. Individual 
ULRs may rate their impact on one aspect of training highly, while having little impact in other areas. In designing a summative index, positive impact across several forms of training was measured.

Responses were coded on a five point Likert scale ranging from 1, 'greatly decreased', to 5, 'greatly increased'. Scores were summed across six variables to produce a 'training index'. Inspection of inter item and item-total correlations did not provide a strong statistical case for excluding any of these items (for descriptive statistics see Appendix B).

For each index, only those ULRs who responded to all of the items are included in the analyses. Although excluding cases with missing data may introduce an element of bias, including such cases by assigning scores based, for example, on the mean or the middle category, can influence the results. The data yielded a reasonably large sample of cases without missing data. For the activity scale, $n=881$ and for the impact on workplace training $n=847$. It was decided, therefore, to exclude cases with missing data on these variables.

\section{Impact on Recruitment and Interest in Union Membership}

To explore the impact of ULR activity on union renewal, two dependent variables were used. The first provides an objective measure of whether or not the respondent had recruited a new member to the union in the previous 12 months (coded $1=y e s, 0=$ no). The second is based on ULRs' perceptions of whether their activities had increased interest in union membership ( $1=y e s, 0=$ no). Seventy-two per cent of the sample had recruited at least one 
new union member and 68 percent believed their ULR activities had increased interest in union membership, suggesting some support for the argument that union learning can result in improved attitudes towards unions, leading to increased membership. It is not argued that these measures represent a proxy for union renewal. Recruitment of new members is only one aspect of improved union organisation and an over-emphasis on recruitment arguably deflects from building sustainable organising capacity (Simms et al., 2013). Nonetheless, in the context of the debate outlined above, the ability of ULRs to recruit, or to generate interest in union membership is a necessary condition for them to have a positive effect on union renewal.

\section{Explanatory Variables}

\section{Workplace characteristics and managerial support}

To test our six propositions related to the 'incorporation thesis', a set of variables to measure organisation size were developed, union density, sector and managerial support. Data measuring these characteristics were not collected at interval level, consequently dummy variables were used in respect of organisation size and union density. For organisation size, the reference category was organisations with 250 or fewer employees and for union density workplaces with union density of 20 percent or less. A further dummy variable was included to indicate whether the workplace was in the public sector, in order to test for any residual 'public sector' effect when other variables were held constant. 
In addition, a set of three dummy variables were developed to gauge the level of support ULRs received from management. The first measured whether or not ULRs received cover for their ULR activities; the second whether the ULRs' workload was reduced to allow them to engage in ULR work. A key development is the introduction of a statutory right to paid time off to undertake ULR activity. Consequently, a dummy variable to measure whether ULRs received reasonable time off to conduct their duties was included.

Taken together these two sets of variables allowed the exploration of arguments that ULR activity and impact in relation to training and union renewal will be largely confined to amenable contexts (Lloyd and Payne, 2007; Mcllroy, 2008).

\section{Collective Workplace Institutions and Negotiation}

To test our six proposals reflecting the 'critical engagement' approach, a third set of explanatory variables was developed to capture the role played by collective workplace institutions of union learning. These have been argued to underpin increased ULR activity and impact (Munro and Rainbird, 2004; Stuart et al., 2013). Separate dummy variables were included to indicate the presence of: a learning agreement; a union learning centre; a formal learning partnership, and a learning committee. Learning partnerships provide the broad context for employer-union co-operation over workplace learning. They are often underpinned by learning agreements, which set out aims and objectives and codify matters such as time off for ULR activity. These aims and objectives can be operationalised through learning committees involving union and management representatives. Finally, union 
learning can be facilitated through union learning centres, which provide a central hub within a workplace for information, advice and provision of union-led training.

For our final explanatory variable, a dummy was developed to specify workplaces where negotiation over training and learning takes place. It has been argued that the inclusion of training within the collective bargaining agenda is critical in stimulating union learning (Heyes and Stuart, 1998). Moreover, evidence has pointed to a link between improved training outcomes from ULR activity and the conduct of negotiation and consultation (Bacon and Hoque, 2010).

\section{Regression Analysis}

Three modelling techniques were used; binary logistic regression; ordered probit and ordinary least squares (OLS) regression, to take account of the different levels of measurement of the dependent variables. For the two single dichotomous dependent variables (measuring recruitment and interest in union membership) binary logistic regression was used. For the two indices, OLS and ordered probit models were estimated. Some commentators argue that the application of the traditional OLS models for ordinal dependent variables is not appropriate (Long 1997; McCullagh 1980) and that an ordered model will produce more reliable estimates. However, because it is based on a 'latent variable' model, it is important to ensure that an ordered model is appropriate for the dependent variable. As a general guide, Long and Freese (2006) suggest that the ordered outcomes should represent an underlying, or latent, continuous outcome that has a natural order. In short, the ordered 
outcomes of the dependent variable should represent discrete categories of an underlying latent scale. The activity index represents an underlying scale measuring levels of ULR activity in relation to training and learning while the training index measures perceived levels of impact on participation in workplace training.

Results generated by the two methods were broadly similar and pointed to the same associations between ULR activity in relation to training and learning, perceived impact on participation in workplace training, and our explanatory variables. However, because the ordered probit model is based on a latent variable model, the coefficients do not have a direct interpretation. Rather, interest lies in the marginal probability effects, that is, the shift in the distribution of the outcome categories associated with a change in the explanatory variables (Boes and Winkelmann, 2006). The composite training index generated values ranging from 6 to 35 (some 29 categories), making comparison of marginal effects cumbersome and difficult to interpret in a meaningful way. Given the similarity of the results generated by the ordered probit and OLS models, the original 29 category dependent variable was retained and the results of the OLS regression are presented. This avoids losing information by collapsing the data into a smaller number of categories suitable for ordered probit regression analysis.

For the ULR activity index, the results of an ordered probit regression and marginal effects for belonging to the last category are presented, that is the marginal effect of having taken part in all five ULR activities in the previous 12 months.

\section{Results}




\section{Proposition 1 - Levels of ULR Activity}

The results of our ordered probit model for levels of ULR activity are presented in Tables 1 and 2. These suggested that workplace characteristics play a key role in shaping activity. Union density (of 80 percent or above) and organisational size (more than 250 employees) were positively associated with levels of activity and both were statistically significant at the one percent level. ULRs in workplaces with union density greater than 80 percent were 13 times more likely to record high levels of activity than those in the reference category (density $<20$ percent). Those in medium sized workplaces (250 to 1000 employees) and those in large workplaces (more than 1,000 employees) were around 11 percent more likely to record high levels of activity than ULRs in smaller workplaces. Overall this suggested that ULRs are likely to prosper in large organisations with strong unions, thus supporting proposition 1a and those who have argued that activity will be limited to conducive contexts (Mcllroy, 2008; Lloyd and Payne, 2007).

Tables 1 and 2 about here

However, a key tenet of this argument is that the lack of statutory support for union learning and emphasis on workplace partnership makes ULRs reliant on managerial support. There was no evidence of this in tables one and two - none of the relationships between aspects of 
managerial support and activity were statistically significant, thus there was little support for proposition $1 \mathrm{~b}$.

In contrast, the critical engagement thesis suggests that the existence of workplace learning institutions both reflects the ability of union learning to stimulate more collective approaches to learning and provides a basis for ULR activity. Support for this, and therefore proposition 1c, was only partial - table one suggested that only the presence of Learning Committees was significantly and positively related to ULR activity. ULRs in such workplaces were around 10 percent more likely to have taken part in all five activities than those where no Learning Committee was present. However, proposition $1 \mathrm{~d}$ was strongly supported as ULR activity was positively and significantly associated with negotiations taking place over learning and training. In fact, ULRs in workplaces where such negotiations took place were 23 percent more likely to score highly on the activity index.

\section{Proposition 2 - Perceived Impact of ULR Activites on Training and Learning Outcomes}

Table 3 sets out our OLS regression to model the perceived impact of ULR activities on training and learning outcomes. Neither workplace characteristics nor items indicating managerial 
support were statistically significant, thus refuting propositions $2 \mathrm{a}$ and $2 \mathrm{~b}$. This suggested that 'structural' factors may not have as great a limiting effect as has been argued previously. Here evidence was consistent with the argument that the impact of ULRs is closely associated with workplace learning institutions and collective bargaining (propositions $2 c$ and $2 d$ ). Table 3 shows a significant effect for joint regulation - in short where either learning agreements were in place, learning committees were in operation, or negotiation over learning and training issues took place, perceived training outcomes were improved. Again, negotiation over training and learning had the largest coefficient, with presence of negotiation associated with a 1.5 increase in 'training' score, when all other explanatory variables were held constant. However, it should be noted that overall, the explanatory power of our model predicting the impact on training was relatively low (Rsq 0.15 ), suggesting that training outcomes were influenced by a much wider range of factors.

\section{Table 3 about here}

\section{Proposition 3 - Recruitment and Interest in Union Membership}

Finally, Table 4 presents two binary logistic regression models, the first models having recruited at least one new member in the previous 12 months', the second 'perceived interest 
in union membership resulting from ULR activity'. These results provide some indication of the potential of ULR activity to enhance union organisation. Following Mcllroy (2008), these effects might be expected to be restricted to workplaces in which the union is already strong (proposition 3a). However, the findings provided only partial support for this.

\section{Table 4 about here}

In respect of recruitment, ULRs in workplaces with density between 61 and 80 per cent were around twice as likely to report having recruited a new member as those in the reference category (density $<20$ percent). This suggests that workplaces with a solid base of membership to work from, but some scope for recruitment, may be most conducive for strengthening union organisation through union learning. However, our results offered only weak support for proposition 3a.

There was little evidence to support proposition $3 \mathrm{~b}$. In Table 4 , none of the managerial support variables were statistically significant at the five percent level. There was little clear relationship between learning institutions and either dependent variable. The exception to this was the presence of learning committees, which was positively related to a perceived increase in interest in union membership. Therefore, only limited support for proposition $3 c$ was found. Table 4 suggested that ULRs in workplaces where negotiation over learning took place were around twice as likely to have recruited at least one new member in the previous 12 months, than those at workplaces where negotiation was absent. They were also around 
twice as likely to report that they believed their work had increased interest in union membership, providing clear support for proposition 3d.

\section{Discussion}

The controversy over the impact of union learning on training, skills and union organisation can be framed in terms of the competing influences of structure and agency. More specifically, it can be argued that the debate revolves around the nature of the inter-relationship between union agency and the structures within which union learning is operationalised (Moore, 2011). For those writers associated with what Stuart and Rainbird (2011) have termed the 'critical engagement thesis', ULRs are able to navigate through, and use, existing structures of union learning to improve training outcomes and extend union influence - for example learning partnerships can provide a foundation for developing joint regulation over training, increasing the profile of union activity and attracting new members. In contrast, the 'incorporation' perspective emphasises the power of structural constraints. Accordingly, the reliance on 'partnership' means that, at best, ULR activity in relation to both training and union renewal will be restricted to settings where trade unions are strong and ULRs enjoy managerial support (Mcllroy, 2008; Lloyd and Payne, 2006; Mcllroy and Croucher, 2013).

The findings outlined above certainly point to the importance of structure in shaping the activity of ULRs, which is likely to be higher in larger organisations with high levels of union density. This is neither surprising nor new (see also Saundry et al., 2010; Bacon and Hoque, 
2008) as greater numbers of union members will generate a greater demand for union learning. However, the evidence in relation to impact was less clear. Although the data suggested that recruitment of new members by ULRs was more likely in organisations with relatively high density, recruitment in less unionised organisations still takes place - around two-thirds of ULRs in organisations with union density below 40 percent had organised courses and recruited new members in the previous 12 months (Saundry et al., 2010).

Perhaps more importantly, the incorporation perspective implies that the structural limitations of union learning render ULRs dependent on managerial approval and therefore likely to act as 'foot soldiers' for managerial interests rather than advancing worker interests (Mcllroy and Croucher, 2009). This is not supported in the analysis above - neither activity nor impact was associated with our proxies for managerial support. In contrast, the critical engagement thesis views collective learning institutions such as partnerships and learning agreements as both a foundation for, and a consequence of, ULR activity and impact. There was little evidence that the existence of learning partnerships and learning centres was influential in shaping activity or outcomes in respect of training and/or union organisation. Furthermore, the presence of a learning agreement was only found to have a positive (and relatively weak) relationship with ULRs' perceptions of their impact on training.

However, the existence of learning committees was positively related to activity and impact in relation to both training and increased interest in union membership. Such committees not only represent evidence of the ULR role being embedded within workplace employment 
relations but also underline the inter-relationship between ULR activity and impact and collective dialogue over learning (Rainbird and Stuart, 2011). Our findings in relation to the role of negotiation over learning and training in determining levels of activity and impact provided some support for this argument. For each of our models, only one factor had a consistently positive effect on activity and impact on learning, generating interest in membership and recruiting new members. Where negotiations took place between ULRs and employers, not only was ULR activity in relation to training and learning likely to be significantly higher, but the impact of that activity was perceived to be greater than in workplaces with no negotiation (see also Bacon and Hoque, 2010). In addition, the likelihood of both having recruited at least one new member to the union and perceiving that ULR activity had increased interest in trade union membership was substantially greater.

It might be argued that the importance of negotiation simply reflects the relative ease of developing ULR activity and delivering outcomes in workplaces with well-developed management-union relations. However, the fact that negotiations over learning exerted an effect independent of both workplace characteristics and managerial support suggests that the role played by ULRs is not diametrically opposed to, but critically intertwined with notions of collective bargaining (cf. Mcllroy and Croucher, 2013).

\section{Conclusion}


Critics of union learning reject claims of structural determinism (Mcllroy and Croucher, 2013) and suggest that their doubts relate to a lack of convincing empirical data. However, their objection is fundamental and rooted in a particular conception of the ULR as playing an advisory role juxtaposed against the traditional bargaining orientation of the shop steward. Furthermore, they argue that any suggestion that ULR activity can stimulate additional organising capacity is stymied by its reliance on the patronage of management.

Our analysis refutes the notion that ULRs are merely managerial 'foot soldiers'. Not only is there little evidence that managerial support is a major influence on the impact of ULR activity, there is a strong and consistent association between the conduct and infrastructure of negotiation over training and the extent to which ULRs affect learning outcomes, the profile of the union and the recruitment of new members. In short, the dichotomy between the 'advisory' role of the ULR and the 'bargaining' orientation of the shop steward, implied by the incorporation perspective is not supported. Instead those institutions which shape ULR activity and impact are those which involve some degree of joint regulation.

This has broad implications for academic debate over union renewal. The duality implicit within the incorporation perspective reflects distinctions between servicing and organising, and partnership and organising, which, as Simms and Holgate (2010) have argued obscures the purpose of organising. The fact that the prime function of ULRs is the provision of learning 'services' to members does not necessarily render them implausible as an engine of increased union activity and organisation. Instead, the key issue which future research should address is the extent to which the ULR role can provide a sustainable route through which new activists are drawn into wider union activism and in turn whether this can be converted into 
enhanced workplace influence and bargaining power. In addition, this research underlines the importance of trade unions taking a broader perspective of the ULR role. In particular, they need to ensure that new ULRs, who may begin with a relatively narrow view of their role, are supported and effectively integrated into existing branch structures, where they will be more likely to link their union learning activity to wider organising and bargaining objectives.

Acknowledgements: The authors are grateful to the financial support of unionlearn with the TUC and for the helpful and constructive comments of the editor and three anonymous reviews

\section{References}

Bacon N, Hoque K (2008) Opening doors to learning. Union learning representative survey report 2008. London: Unionlearn.

Bacon N. Hoque K (2009) The impact of the union learning representatives, a survey of ULRs and their employers. London: Unionlearn. 
Bacon N, Hoque K (2010) Union representation and training; the impact of Union Learning Representatives and the factors influencing their effectiveness. Human Relations 64(3): 387413.

Boes S, Winkelmann R (2006) Ordered Response Models. Allgemeines Statistisches Archiv 90(1): 165-180.

Cassell C, and Lee B (2007) Re-vitalising learning and development: exploring the role of the trade union representative. Personnel Review 36(5): 781-99.

Cassell C, Lee B (2009) Trade union representatives: progressing partnership? Work, Employment and Society 23(2): 213-230.

Clough B (2010) The origins, role and impact of union learning representatives in the UK and other countries. Working Article No. 1. London: unionlearn.

Dex S, McCulloch A (1998) The Reliability of Retrospective Unemployment History Data. Work, Employment and Society 12(3): 497-509.

Ewing K (2005) The Function of Trade Unions. Industrial Law Journal 34(1): 1-22. 
Findlay P, Warhurst C (2011) Union learning funds and trade union revitalization: A new tool in the toolkit? British Journal of Industrial Relations 49(Supplement s1): s115-s134.

Heyes J, Rainbird H (2011) Mobilising resources for union learning: a strategy for revitalisation? Industrial Relations Journal 42(6): 565-579.

Heyes J, Stuart M (1998) Bargaining for skills: Trade unions and training at the workplace. British Journal of Industrial Relations 36(3): 459-467.

Hoque K, Bacon N (2008) Trade unions, learning and employer-provided training in Britain. British Journal of Industrial Relations 46(4): 702-31.

Hoque K, Bacon N (2011) Assessing the impact of Union Learning Representatives on training: evidence from a matched sample of ULRs and managers. Work, Employment and Society 25(2): 218-233.

Lee B, Cassell C (2009) Learning organizations, employee development and learning representative schemes in the UK and New Zealand. Journal of Workplace Learning 21 (1): 522. 
Lloyd C, Payne J (2006) British trade unions and the learning and skills agenda: an assessment. SKOPE Issues Article 12. Oxford and Cardiff Universities.

Lloyd C, and Payne J (2007) Tackling the UK skills problem: can unions make a difference? In: Shelley S, and Calveley M (eds) Learning with Trade Unions: A Contemporary Agenda in Employment Relations. Aldershot: Ashgate, 57-80.

Long S (1997) Regression Models for Categorical and Limited Dependent Variables. Thousand Oaks: Sage.

Long S, Freese J (2006) Regression Models for Categorical Dependent Variables Using Stata. 2nd Edition. Stata Press.

McCullagh P (1980) Regression Models for Ordinal Data. Journal of the Royal Statistical Society, Series B (Methodological) 42: 109-142.

Mcllroy J (2008) Ten Years of New Labour: Workplace Learning, social partnership and union revitalization in Britain. British Journal of Industrial Relations 46(2):283-313. 
Mcllroy J, Croucher R (2009) Skills and training: A strategic role for trade unions or the limits of neoliberalism? In Daniels G, Mcllroy J (eds) Trade Unions in a Neoliberal World: British Trade Unions Under New Labour. London: Routledge, 283-315.

Mcllroy J, Croucher R (2013) British trade unions and the academics: the case of Unionlearn. Capital and Class 37 (2): 263-284.

Moore S (2011) New trade union activism - class consciousness or social identity? Basingstoke: Palgrave Macmillan.

Moore S, Wood H (2007) Union learning, union recruitment and organising. London: Unionlearn.

Munro A, Rainbird H (2004) Opening Doors as Well as Banging on Tables: An Assessment of Unison/Employer Partnerships on Learning in the Public Sector. Industrial Relations Journal 35(5): 419-433.

Mustchin S (2012) Unions, learning, migrant workers and union revitalization in Britain. Work, Employment and Society 26(6): 951-967 
Rainbird H (2005) Assessing Partnership Approaches to Lifelong Learning: A New and Modern Role for the Trade Unions? In: Stuart M, Martinez Lucio M (eds) Partnership and Modernisation in Employment Relation. London: Routledge, 26-62.

Rainbird H, Stuart M (2011) The state and the union learning agenda in Britain. Work, Employment and Society 25(2): 202-17.

Saundry R, Hollinrake A and Antcliff V (2010) Learning Works, Report of the 2009 survey of union learning representatives and their managers. London: unionlearn.

Simms M, Holgate J (2010) Organising for what? Where is the debate on the politics of organising? Work Employment and Society 24 (1): 157-68.

Simms M, Holgate J, and Heery E (2013) Union voices-Tactics and tensions in UK Organizing. Ithaca: ILR Press.

Stuart M, Cutter J, Cook H, and Winterton J (2013) Who stands to gain from union-led learning in Britain? Evidence from surveys of learners, union officers and employers. Economic and Industrial Democracy 34(2): $227-246$. 
Stuart M, Robinson A (2007) Training, Union Recognition and Collective Bargaining: Findings from the 2004 Workplace Employment Relations Survey: An Analytical Note for the TUC. Unionlearn Research Article No. 4. London: Unionlearn.

Thompson P, Warhurst C, and Findlay P (2007) Organising to learn and learning to organise. London: Unionlearn.

Unionlearn (2011) Learning for Life - Annual Conference Report 2010. London: Unionlearn.

Unionlearn (2015) Changing Lives Through Learning: Unionlearn Annual Report 2015. London: Unionlearn.

van Wanrooy B, Bewley H, Bryson A, Forth J, Freeth S, Stokes L, and Wood S (2013) Employment Relations in the Shadow of Recession - Findings from the 2011 Workplace Employment Relations Study. London: Palgrave Macmillan.

Wallis E, Stuart M, and Greenwood I (2005) Learners of the workplace unite! Work, Employment and Society 19(2): 283-304. 
Wood H, Moore S (2004) The Union Learning Experience: National Survey of Union Officers and ULRs. Summary Report. London: Working Lives Research Institute. 


\section{Author Biographies:}

Richard Saundry is Professor of HRM and Employment Relations at Plymouth Graduate School of Management, Plymouth University

Valerie Antcliff is a Research Fellow at the Centre for Enterprise, Manchester Metropolitan University

Alison Hollinrake is a Senior Lecturer in Employee Development and a member of the Institute for Research into Organisations, Work and Employment, University of Central Lancashire 


\section{Appendix A - Dependent Variables}

\section{ULR Activity Index}

Responses are dichotomies coded 1=yes $0=$ no.

\begin{tabular}{|l|l|}
\hline Question: & Mean \\
\hline Provided information and advice to colleagues on learning opportunities? & 0.94 \\
\hline Helped colleagues to get funding for learning? & 0.48 \\
\hline Arranged (or helped to arrange) courses for colleagues? & 0.76 \\
\hline Conducted a learning needs assessment? & 0.52 \\
\hline Met and/or networked with ULRs from other workplaces? & 0.78 \\
\hline
\end{tabular}

$N=881$

Scale Min O Max 5

Scale mean 3.5 Standard deviation 1.4 Cronbach's Alpha 64

\section{ULR Impact on Workplace Training Index}

Responses are coded using a five point Likert scale ranging from 1 greatly decreased to 5 greatly increased

\begin{tabular}{|l|l|}
\hline Question: & Mean \\
\hline Has the no. of your members involved in: & \\
\hline - training leading to vocational /academic qualification been affected by your ULR & 3.73 \\
\hline activity & \\
\hline - apprenticeships been affected by your ULR activity & 3.12 \\
\hline - job-related training not leading to formal qualifications been affected by your & 3.50 \\
\hline ULR activity & \\
\hline
\end{tabular}




\begin{tabular}{|l|l|}
\hline - training in basic numeracy and literacy skills been affected by your ULR activity & 3.73 \\
\hline - continuing professional development been affected by your ULR activity & 3.55 \\
\hline - personal interest/ leisure courses been affected by your ULR activity & 3.58 \\
\hline
\end{tabular}

$N=674 \operatorname{Min} 6 \max 35$

Scale mean 21.2 Standard deviation 3.3 Cronbach's Alpha .77 
Appendix B - Explanatory Dummy Variables

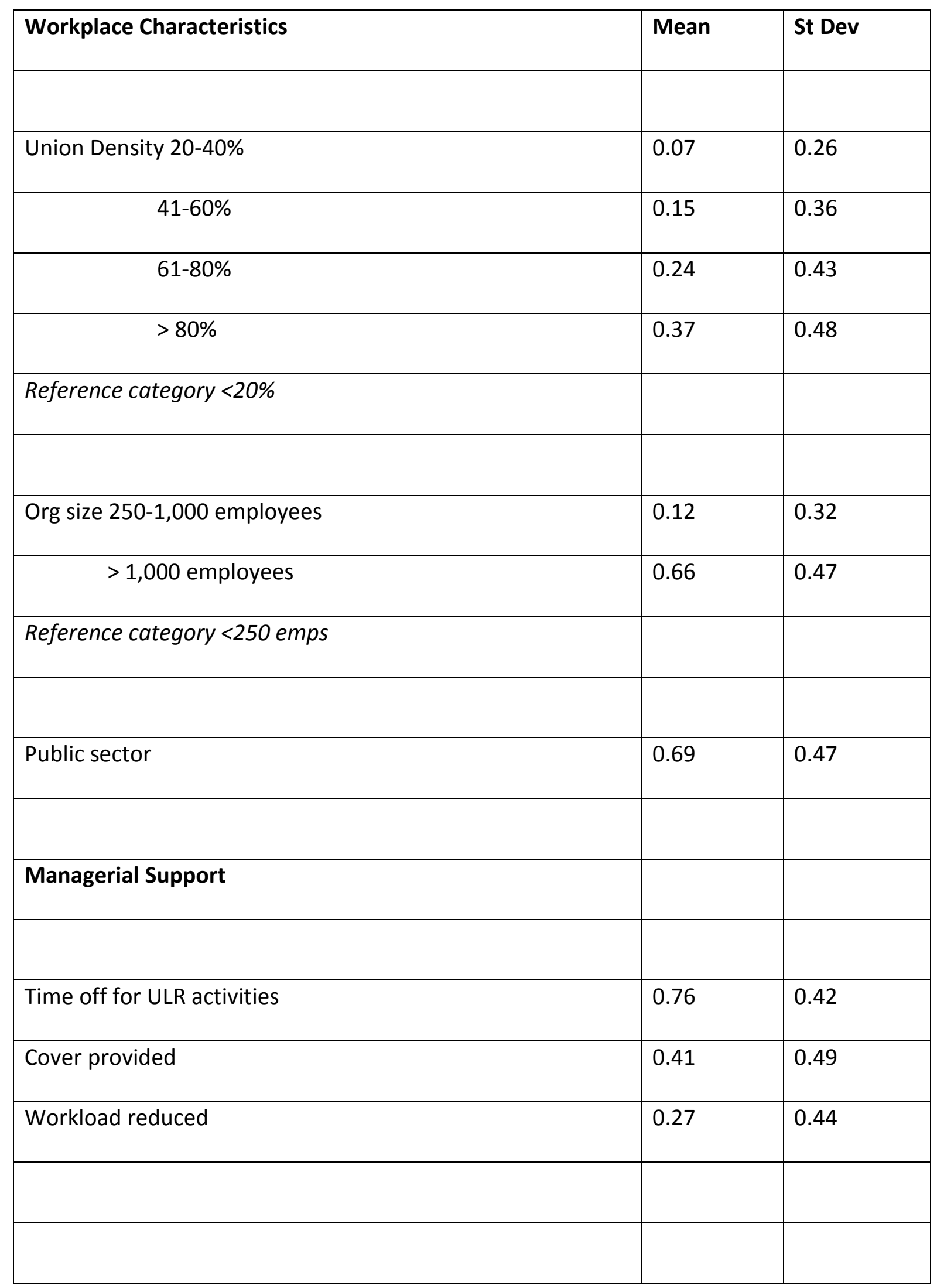




\begin{tabular}{|l|l|l|}
\hline Collective Workplace Institutions & & \\
\hline & 0.64 & 0.48 \\
\hline Formal Learning Agreement & 0.54 & 0.49 \\
\hline Formal Learning Partnership & 0.56 & 0.49 \\
\hline Learning committees & 0.32 & 0.46 \\
\hline Learning Centre & & \\
\hline & & \\
\hline Negotiation & & \\
\hline & 0.65 & 0.47 \\
\hline Negotiation over training and learning & & \\
\hline
\end{tabular}


Table 1 - Ordered Probit Model for the Activity Index

\begin{tabular}{|c|c|c|c|c|}
\hline & \multicolumn{4}{|c|}{ Activity Index } \\
\hline & Coef. & $\begin{array}{l}\text { Std. } \\
\text { Err. }\end{array}$ & Z statistic & $P(z)^{1}$ \\
\hline \multicolumn{5}{|l|}{ Workplace Characteristics } \\
\hline Union Density $20-40 \%$ & 0.209 & 0.213 & 0.98 & 0.328 \\
\hline Union Density 41-60\% & -0.172 & 0.174 & -0.98 & 0.323 \\
\hline Union Density 61-80\% & 0.216 & 0.165 & 1.31 & 0.192 \\
\hline Union Density $>80 \%$ & $0.443 * *$ & 0.158 & 2.80 & 0.005 \\
\hline Public Sector & 0.122 & 0.103 & 1.18 & 0.234 \\
\hline Org size $251-1000$ employees & $0.359 *$ & 0.167 & 2.15 & 0.032 \\
\hline Org size $>1000$ employees & $0.367 * *$ & 0.119 & 3.08 & 0.002 \\
\hline \multicolumn{5}{|l|}{ Management Support } \\
\hline Time off for ULR activity dummy & 0.047 & 0.124 & 0.37 & 0.707 \\
\hline Provide cover dummy & -0.021 & 0.108 & -0.19 & 0.848 \\
\hline Reduced workload dummy & 0.192 & 0.114 & 1.68 & 0.092 \\
\hline \multicolumn{5}{|l|}{ Collective Workplace Institutions } \\
\hline Formal Learning Agreement dummy & 0.109 & 0.119 & 0.95 & 0.357 \\
\hline Formal Learning Partnership dummy & 0.068 & 0.114 & 0.59 & 0.553 \\
\hline Learning Centre dummy & 0.153 & 0.109 & 1.40 & 0.161 \\
\hline Learning committees dummy & $0.311^{*}$ & 0.104 & 2.99 & 0.003 \\
\hline Negotiation & & & & \\
\hline
\end{tabular}

\footnotetext{
${ }^{1} p$-value for the $z$ statistics which test for the null hypothesis that an individual predictor's regression coefficient is zero given that the rest of the predictors are in the model. The test statistic $\boldsymbol{z}$ is calculated as the ratio of the Coef. to the Std. Err. of the respective predictor
} 


\begin{tabular}{|l|l|l|l|l|}
\hline Negotiate over Training and Learning & $0.723^{*}$ & 0.105 & 6.88 & 0.000 \\
\hline No of observations & 583 & & & \\
\hline Prob > chi2 & 0.00 & & & \\
\hline
\end{tabular}

$* * p>.01 * p<.05$ 
Table 2 - Marginal Effects of Scoring 5 on the Activity Index

\begin{tabular}{|c|c|}
\hline & Marginal Effects \\
\hline \multicolumn{2}{|l|}{ Workplace Characteristics } \\
\hline Union Density $20-40 \%$ & 0.065 \\
\hline Union Density 41-60\% & -0.054 \\
\hline Union Density $61-80 \%$ & 0.067 \\
\hline Union Density $>80 \%$ & 0.130 \\
\hline Public Sector & 0.038 \\
\hline Org size $251-1000$ employees & 0.112 \\
\hline Org size $>1000$ employees & 0.115 \\
\hline \multicolumn{2}{|l|}{ Management Support } \\
\hline Time off for ULR activity dummy & 0.014 \\
\hline Provide cover dummy & -0.006 \\
\hline Reduced workload dummy & 0.060 \\
\hline \multicolumn{2}{|l|}{ Collective Workplace Institutions } \\
\hline Formal Learning Agreement dummy & 0.034 \\
\hline Formal Learning Partnership dummy & 0.021 \\
\hline Learning Centre dummy & 0.048 \\
\hline Learning committees dummy & 0.097 \\
\hline \multicolumn{2}{|l|}{ Negotiation } \\
\hline Negotiate over Training and Learning & 0.227 \\
\hline
\end{tabular}


Table 3 - OLS Regression Model for ULR Impact on Training Index

\begin{tabular}{|c|c|c|c|}
\hline ULR Impact on Training & Coef. & Std. Err. & $P$ \\
\hline \multicolumn{4}{|l|}{ Workplace Characteristics } \\
\hline Union Density $20-40 \%$ & 0.009 & 0.656 & 0.989 \\
\hline Union Density 41-60\% & -0.837 & 0.536 & 0.119 \\
\hline Union Density 61-80\% & 0.283 & 0.508 & 0.577 \\
\hline Union Density $>80 \%$ & 0.031 & 0.484 & 0.949 \\
\hline Public Sector & 0.215 & 0.307 & 0.484 \\
\hline Org size $251-1000$ employees & -0.068 & 0.505 & 0.892 \\
\hline Org size $>1000$ employees & -0.161 & 0.359 & 0.653 \\
\hline \multicolumn{4}{|l|}{ Management Support } \\
\hline Time off for ULR activity dummy & 0.519 & 0.379 & 0.171 \\
\hline Provide cover dummy & -0.453 & 0.325 & 0.164 \\
\hline Reduced workload dummy & 0.074 & 0.341 & 0.828 \\
\hline \multicolumn{4}{|l|}{ Collective Workplace Institutions } \\
\hline Formal Learning Agreement dummy & $0.803^{*}$ & 0.359 & 0.026 \\
\hline Formal Learning Partnership dummy & 0.472 & 0.340 & 0.166 \\
\hline Learning Centre dummy & 0.210 & 0.323 & 0.515 \\
\hline Learning committees dummy & $0.903 * *$ & 0.317 & 0.005 \\
\hline & & & \\
\hline
\end{tabular}




\begin{tabular}{|l|l|l|l|}
\hline Negotiation & & & \\
\hline Negotiate over Training and Learning & $1.531^{* *}$ & 0.322 & 0.000 \\
\hline cons & 18.858 & 0.597 & 0.000 \\
\hline $\mathrm{N}=$ & 587 & & \\
\hline R sq & 0.15 & & \\
\hline
\end{tabular}

$* * p<.01 * p<.05$ 
Table 4 - Binary Logistic Models for Recruiting and Increasing Interest in Union Membership in the previous 12 months

\begin{tabular}{|c|c|c|}
\hline & $\begin{array}{l}\text { Recruited a } \\
\text { member }\end{array}$ & $\begin{array}{l}\text { Increased interest in union } \\
\text { membership }\end{array}$ \\
\hline & Odds Ratio & Odds Ratio \\
\hline \multicolumn{3}{|l|}{ Workplace characteristics } \\
\hline Union Density $20-40 \%$ & 0.976 & 1.050 \\
\hline Union Density 41-60\% & 1.293 & 1.282 \\
\hline Union Density 61-80\% & $2.264^{* *}$ & $2.608^{* *}$ \\
\hline Union Density $>80 \%$ & 1.463 & 1.501 \\
\hline Public Sector & 1.085 & 1.121 \\
\hline Org size $251-1000$ employees & 0.957 & 0.552 \\
\hline Org size $>1000$ employees & 1.253 & 0.358 \\
\hline \multicolumn{3}{|l|}{ Management support } \\
\hline Time off for ULR activity dummy & 0.848 & 1.040 \\
\hline Provide cover dummy & 1.265 & 1.566 \\
\hline Reduced workload dummy & 1.100 & 1.293 \\
\hline \multicolumn{3}{|l|}{ Collective workplace institutions } \\
\hline Formal Learning Agreement dummy & 0.928 & 0.928 \\
\hline Formal Learning Partnership dummy & 1.067 & 0.980 \\
\hline Learning Centre dummy & 0.650 & 0.808 \\
\hline Learning committees dummy & 1.120 & $1.546^{*}$ \\
\hline Negotiation & & \\
\hline
\end{tabular}




\begin{tabular}{|l|l|l|}
\hline Negotiate over Training and & $2.055^{* *}$ & $1.990^{* *}$ \\
\hline Learning & & \\
\hline Number of observations & 1.38 & 0.801 \\
\hline Log likelihood & 611 & 608 \\
\hline
\end{tabular}

$* * p<.01 * p<.05$ 